\title{
USE OF BASIC SALTS OF IRON AND ZINC AS PLANT AMEND- MENTS IN SOILS
}

\section{P. Arambarri, F. Cabrera, O. Garcia, and M. Galvez}

Instituto de Recursos Naturales y Agrobiologia de Sevilla, CSIC, Apartado 1052, Sevilla 41080, Spain

ABSTRACT: In a greenhouse experiment, the effects of adding zinc $(\mathrm{Zn})$ and iron (Fe) as either their basic salts or as commercial chelates were compared for the production of lettuce. The basic salts were found to be as effective as the chelates in providing $\mathrm{Zn}$ and $\mathrm{Fe}$ as well as being more environmentally safe.

\section{INTRODUCTION}

Calcareous soils frequently supply insufficient quantities of $\mathrm{Zn}$ and $\mathrm{Fe}$ for normal plant growth. Therefore, a common practice is to apply chelates of $\mathrm{Zn}$ and Fe to such soils to satisfy the crop requirement (Wallace and Lunt, 1956; Wallace, 1983; Wallace and Wallace, 1983a). However, the synthetic chelating agents are frequently too expensive to be used in general field agriculture and are difficult to supply at the correct concentration. This has led to the search for alternative sources of these micronutrients (Mortvedt, 1986; Wempati and Loeppert, 1986; Parpian and Anderson, 1988). Chelating agents can be toxic to plants when used in excess and have been found to inhibit the uptake of other cations by plant roots (Wallace, 1983; Wallace and Wallace, 1983b). In adition, these heavy metals must not be applied in excess since they can have deleterious environmental effects, such as the depression of the nitrogen-fixing microbial populations in soils (McGrath et al., 1988).

Basic salts of many of the heavy metals are intermediately soluble between those of the simple salts and those of the hydroxides, so they could be considered 
as 'slow release' when added to soils as an alternative source of plant micronutrients. Unlike the chelates, basic salts are not stable in solution, so they cannot promote the movement of cations and other heavy metals down the soil profile. Basic salts are crystalline, easy to handle, and do not introduce any foreign component into the environment. Thus, they could be considered as being environmentally safe.

In a previous paper (Galvez et al., 1987), it was shown that addition of the basic salts of $\mathrm{Zn}$, copper $(\mathrm{Cu})$, and cobalt $(\mathrm{Co})$ to a sandy soil resulted in values for their 'capacity factor' (I/Q) (Mattingly, 1965) lower than those for their simple salts but higher than for their corresponding hydroxides.

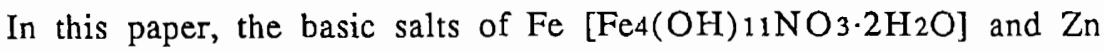
$\left[\mathrm{Zn} 5(\mathrm{OH})_{8} \mathrm{Cl}_{2} \cdot \mathrm{H}_{2} \mathrm{O}\right]$ were used in a greenhouse experiment to evaluate the effect of their addition to a sand and to a calcareous sandy soil on the weight and nutritional status of lettuce (Lactuca sativa $\mathrm{L}$.) plants. The results were compared with those obtained by using the commercially available chelates of $\mathrm{Fe}$ and $\mathrm{Zn}$ as soil amendments.

The basic salt of $\mathrm{Fe}, \mathrm{Fe}_{4}(\mathrm{OH}) 11 \mathrm{NO}_{3} \cdot 2 \mathrm{H}_{2} \mathrm{O}$, referred to as bFe, has recently being synthetized (Lopez-Delgado et al., 1988) and has been used as a plant nutrient for the first time in this experiment. The use of the basic salt of $\mathrm{Zn}$, $\mathrm{Zn} 5(\mathrm{OH}) 8 \mathrm{Cl}_{2} \cdot \mathrm{H}_{2} \mathrm{O}$, referred to as $\mathrm{bZn}$, to correct deficiencies of this element in plants, animals, and human beings is protected by a patent (P9300705).

\section{MATERIALS AND METHODS}

The experiment was carried out in a greenhouse using ca. $0.15 / \mathrm{m}^{3}$-capacity containers fulled with either sand or a calcareous sandy soil (from now on soil). Some characteristics of the sand and soil are shown in Table 1. Four lettuce plants were planted in each container, three to be sampled after 40,70 , or 100 days, respectively, leaving the fourth to be sampled at the flower stage.

A factorial experiment with five different treatments was set up to compare the effects of the addition to the soil of the basic salts, $b F e$ and $b Z n$, with those of two commercial chelates (Sandofer R, 6\% Fe as EDDHA; Bundolin Corrector Zn-14 $\mathrm{R}, 14 \% \mathrm{Zn}$ as EDTA, referred to as chFe and chZn, respectively). In two of these, mixtures of the basic salts and the commercial chelates were applied: treatment $\mathrm{bZnchFe}$ (the basic salt of $\mathrm{Zn}$ plus chelate of $\mathrm{Fe}$ ) and treatment ch $\mathrm{ZnbFe}$ 
TABLE 1. Some Characteristics of the Sand and the Calcareous Sandy Soil Used.

\section{Mechanical Analysis}

$\underset{(\mathrm{H} 2 \mathrm{O})}{\mathrm{pH}} \quad \mathrm{CaCO}_{3} \quad$ Coarse Sand Fine Sand Silt Clay

\begin{tabular}{lllllll}
\hline Soil & 8.5 & 8.6 & 87.4 & 2.5 & 2.5 & 7.6 \\
Sand & 6.3 & 0.0 & 98.3 & 1.2 & 0.4 & 0.1 \\
\hline
\end{tabular}

\begin{tabular}{cccc}
\multicolumn{4}{c}{ DTPA-Extracted Micronutrients, $\mu \mathrm{g} / \mathrm{g}$} \\
\hline $\mathrm{Fe}$ & $\mathrm{Cu}$ & $\mathrm{Mn}$ & $\mathrm{Zn}$ \\
\hline 3.6 & 0.2 & 1.2 & 0.5 \\
1.4 & 0.06 & 0.3 & 0.12
\end{tabular}

(the chelate of $\mathrm{Zn}$ plus the basic salt of $\mathrm{Fe}$ ). In the third treatment, there was no addition of either $\mathrm{Zn}$ or $\mathrm{Fe}$ (treatment zero). The other two treatments were chelates alone, chZnchFe and basic salts alone, bZnbFe. Each treatment was replicated three times. The applications of $\mathrm{Zn}$ and Fe corresponded to normal agricultural practice, i.e. the corresponding weights of chelates and basic salts, equivalent to $7 \mathrm{Zn} \mathrm{kg} / \mathrm{ha}$ and $3 \mathrm{Fe} \mathrm{kg} / \mathrm{ha}$, respectively. Another experiment was conducted to compare normal ( $\mathrm{bZnbFe}$ ), half $(1 / 2 \mathrm{bZnl} / 2 \mathrm{bFe}$ ) and double $(2 \mathrm{bZn} 2 \mathrm{bFe})$ doses of basic salts.

In all experiments, each container received a NPK fertilization equivalent to 50,30 , and $200 \mathrm{~kg} / \mathrm{ha}$ of $\mathrm{N}$ (3.4 g as $\mathrm{NH}_{4} \mathrm{NO}_{3} \mathrm{~A} . \mathrm{R}$. per container), $\mathrm{P}_{2} \mathrm{O} 5$ (1.3 g as $\mathrm{Ca}\left(\mathrm{H}_{2} \mathrm{PO}_{4}\right) 2 \cdot \mathrm{H}_{2} \mathrm{O}$ A.R. per container), and $\mathrm{K}_{2} \mathrm{O}(3.8 \mathrm{~g}$ as $\mathrm{KCl}$ A.R. per container). The containers were periodically watered with a basal nutrient solution in deionised water which contained all the essential macro- and micro-nutrients, except $\mathrm{Zn}$ and $\mathrm{Fe}$.

Aerial parts of plants were taken at three stages of growth as mentioned above, weighed, and prepared for analysis. Leaves were washed several times 
with deionised water, dried at $60^{\circ} \mathrm{C}$ for $24 \mathrm{~h}$, and ground. For the $\mathrm{P}, \mathrm{K}, \mathrm{Ca}, \mathrm{Mg}$, $\mathrm{Na}, \mathrm{Fe}, \mathrm{Cu}, \mathrm{Mn}$, and $\mathrm{Zn}$ determinations, the dried leaf subsamples were ashed and treated with concentrated $\mathrm{HCl}$ on a hot plate (Pinta, 1973; Pinta et al., 1973). The $\mathrm{P}$ in solution was analysed by the method of Murphy and Riley (1962), Na and $\mathrm{K}$ by flame emission spectrophotometry, and the remaining elements by atomic absorption spectrophotometry. Nitrogen was determined after Kjeldahl digestion (Pinta et al., 1973). The analytical measurements were checked against a known plant standard (Olea europaean, CRM062).

Data analysis were carried out using the STATIGRAFICS package. Monofactorial ANOVAs were used to test treatment effect on measured variables: When a significant effect was detected, TUCKEY's test was used to compare means. A significance level of $P<0.05$ was used throughout the study.

\section{RESULTS AND DISCUSSION}

Mean values of the weight of plants and the concentrations of $\mathrm{N}, \mathrm{P}, \mathrm{K}, \mathrm{Ca}$, $\mathrm{Mg}$, and $\mathrm{Na}$ in leaves at the three stages of growth for the lettuce grown in sand are given in Table 2. In general, no significant differences between the weights and the nutritional status of the plants for the five treatments were found at any stage of growth. Although some differences were observed between the mean values of $\mathrm{N}, \mathrm{P}, \mathrm{K}, \mathrm{Ca}, \mathrm{Mg}$, and $\mathrm{Na}$ contents of the lettuce leaves from plants receiving different treatments, the mean values were always within the ranges considered as normal (Geralson et al., 1973; Wolnik et al., 1983) regardless of the form in which both $\mathrm{Zn}$ and Fe were applied. Similar results were found for lettuce grown in soil with no significant differences between treatments. All of these results indicate that the basic salts are as good as the chelates for supplying both $\mathrm{Zn}$ and $\mathrm{Fe}$.

However when the content of micronutrients in the lettuce leaves was calculated, some differences appeared (Table 3). Using sand as the substrate, the chelates (chZnchFe treatment) supplied significantly more Fe to the lettuce plant. In contrast in calcareous soil, the basic salts and chelates did not differ significantly for supplying $\mathrm{Fe}$ due possibly to the effect of the active carbonate present. For $\mathrm{Zn}$, the chelate was more effective than the basic salt in providing $\mathrm{Zn}$ to the lettuce plant, whether the substrate is either soil or sand. The $\mathrm{Mn}$ and $\mathrm{Cu}$ contents did not reflect any cause or effect relationship with treatment, but the 
TABLE 2. Weight and Nutritional Status of Plants of Lactuca sativa $\mathrm{L}$. at Different Stages of Growth in Sand (Mean values of three replicates in $g$ or \% dry weight).

Element Stage of

Treatment Applied Growth

zero bZnbFe chZnchFe bZnchFe chZnbFe

Weight, $g$

$\begin{array}{lr}1 & 70.4 \mathrm{a} \\ 2 & 218.9 \mathrm{a} \\ 3 & 275.8 \mathrm{a}\end{array}$

$84.3 \mathrm{a}$
$208.4 \mathrm{a}$
$284.9 \mathrm{a}$

$\begin{array}{rrr}64.7 \mathrm{a} & 67.7 \mathrm{a} & 55.8 \mathrm{a} \\ 216.8 \mathrm{a} & 172.6 \mathrm{a} & 204.1 \mathrm{a} \\ 226.8 \mathrm{a} & 228.5 \mathrm{a} & 240.1 \mathrm{a}\end{array}$

$N, \%$

1
2
3

$\mathrm{P}, \%$

1
2
3

$3.45 \mathrm{a}$
$2.66 \mathrm{a}$
$2.68 \mathrm{ab}$

\begin{abstract}
$2.70 \mathrm{a}$
\end{abstract}
$2.59 \mathrm{a}$

$3.31 \mathrm{a}$

$2.57 \mathrm{a}$

$2.55 \mathrm{a}$

$2.53 \mathrm{a}$

$3.39 \mathrm{a}$

$2.47 \mathrm{a}$

$2.62 \mathrm{a}$

$3.29 \mathrm{a}$

$2.66 \mathrm{a}$

$2.99 \mathrm{~b}$

$\mathrm{P}, \%$

$0.41 \mathrm{a}$
$0.34 \mathrm{a}$
$0.30 \mathrm{a}$

$0.34 \mathrm{a}$

$0.37 \mathrm{a}$

$0.33 \mathrm{a}$

$0.36 a$

$0.35 \mathrm{a}$

$0.30 \mathrm{a}$

$0.31 \mathrm{a}$

$0.31 \mathrm{a}$

$0.26 \mathrm{a}$

$0.27 \mathrm{a}$

$0.38 \mathrm{a}$

$0.41 \mathrm{a}$

$\mathrm{K}, \%$

1
2
3

$4.97 \mathrm{c}$

4.30a

$4.77 \mathrm{bc}$

$4.20 \mathrm{a}$

$4.50 \mathrm{ab}$

$4.33 \mathrm{a}^{\prime}$

$3.97 \mathrm{a}$

$4.71 \mathrm{a}$

$5.04 \mathrm{a}$

$4.10 \mathrm{a}$

$4.13 \mathrm{a}$

$4.88 \mathrm{a}$

$5.18 \mathrm{a}$

4.23a

$4.84 \mathrm{a}$

$\mathrm{Ca}, \%$

1
2
3

$1.12 \mathrm{a}$

$1.14 \mathrm{a}$

$1.41 \mathrm{a}$

$1.23 \mathrm{a}$

$1.10 \mathrm{a}$

$1.05 \mathrm{a}$

$1.00 \mathrm{a}$

$1.16 \mathrm{a}$

$1.56 \mathrm{ab}$

$1.90 \mathrm{~b}$

$1.57 \mathrm{ab}$

$0.94 \mathrm{a}$

$1.85 \mathrm{ab}$

$0.25 \mathrm{a}$

$0.29 \mathrm{a}$

$0.26 \mathrm{a}$

$1.21 \mathrm{a}$

$\mathrm{Mg}, \%$

1
2
3

$0.26 \mathrm{a}$

$0.20 \mathrm{a}$

$0.23 \mathrm{a}$

$0.23 \mathrm{a}$

$0.28 \mathrm{a}$

$0.32 \mathrm{a}$

$0.27 \mathrm{a}$

$0.32 \mathrm{a}$

$0.26 \mathrm{a}$

$0.20 \mathrm{a}$

$0.24 \mathrm{a}$

$\mathrm{Na}, \%$

$\begin{array}{ll}1 & 0.67 \mathrm{a} \\ 2 & 0.55 \mathrm{a} \\ 3 & 0.60 \mathrm{a}\end{array}$

$0.71 \mathrm{a}$

$0.66 \mathrm{a}$

$0.72 \mathrm{a}$

$0.58 \mathrm{a}$

$0.58 \mathrm{a}$

$0.73 \mathrm{a}$

$0.66 \mathrm{a}$

$0.66 \mathrm{a}$

$0.68 \mathrm{a}$

$0.73 \mathrm{a}$

Values followed by the same letter in the same row, do not differ significantly $(\mathrm{P}<0.05)$.

absence of the chelate was clearly reflected in an increase in $\mathrm{Mn}$ content in the leaves for lettuce grown in soil (zero treatment). Leaf $\mathrm{Cu}$ contents for lettuce plants grown in sand (not shown) were very high (ca. $35 \mathrm{ppm}$ ) and similar for all treatments and stages of growth, reflecting contamination by a $\mathrm{Cu}$-containing fungicide which had to be applied several times on the plants. 
TABLE 3. Micronutrient Composition of Plants of Lactuca sativa L.at Different Stages of Growth. (Mean value of three replicates in $\mu \mathrm{g} / \mathrm{g}$ dry weight).

\begin{tabular}{|c|c|c|c|c|c|c|}
\hline \multirow[t]{2}{*}{ Element } & \multirow{2}{*}{$\begin{array}{l}\text { Substrate } \\
\text { Used }\end{array}$} & \multirow{2}{*}{$\begin{array}{l}\text { Stage of } \\
\text { Growth }\end{array}$} & \multicolumn{4}{|c|}{ Treatment Applied } \\
\hline & & & \multirow{3}{*}{$\begin{array}{r}\text { zero } \\
47 \mathrm{a} \\
50 \mathrm{a} \\
63 \mathrm{a}\end{array}$} & \multicolumn{2}{|c|}{ chZnchFe bZnchFe } & \multirow{3}{*}{$\begin{array}{c}\text { chZnbFe } \\
34 a \\
55 a \\
82 a\end{array}$} \\
\hline \multirow{5}{*}{$\mathrm{Fe}, \mu \mathrm{g} / \mathrm{g}$} & Soil & 1 & & $43 a$ & $44 \mathrm{a}$ & \\
\hline & & $\begin{array}{l}2 \\
3\end{array}$ & & $\begin{array}{l}52 \mathrm{a} \\
77 \mathrm{a}\end{array}$ & $\begin{array}{l}38 \mathrm{a} \\
78 \mathrm{a}\end{array}$ & \\
\hline & Sand & 1 & & & & \\
\hline & & 2 & $67 a$ & $117 \mathrm{c}$ & $73 \mathrm{ab}$ & $100 \mathrm{bc}$ \\
\hline & & 3 & $148 \mathrm{ab}$ & $235 \mathrm{c}$ & $139 \mathrm{ab}$ & $160 \mathrm{~b}$ \\
\hline \multirow{6}{*}{$\mathrm{Zn}, \mu \mathrm{g} / \mathrm{g}$} & Soil ${ }^{1}$ & 1 & $15 \mathrm{a}$ & $31 \mathrm{~b}$ & $15 \mathrm{a}$ & $37 b^{\prime}$ \\
\hline & & 2 & $15 \mathrm{a}$ & $30 \mathrm{~b}$ & $14 \mathrm{a}$ & $54 c$ \\
\hline & & & & & & \\
\hline & Sand & 1 & $25 a$ & $52 c$ & $26 a$ & $36 \mathrm{~b}$ \\
\hline & & $\begin{array}{l}2 \\
3\end{array}$ & $\begin{array}{l}33 a \\
48 a\end{array}$ & $43 c$ & $27 \mathrm{a}$ & $40 \mathrm{bc}$ \\
\hline & & & & & & \\
\hline \multirow{5}{*}{$\mathrm{Mn}, \mu \mathrm{g} / \mathrm{g}$} & Soil & 1 & $25 \mathrm{a}$ & $7 a$ & $14 c$ & $10 \mathrm{~b}$ \\
\hline & & $\begin{array}{l}2 \\
3\end{array}$ & $\begin{array}{l}22 a b \\
57 c\end{array}$ & $\begin{array}{r}6 a \\
43 b\end{array}$ & $\begin{array}{l}14 \mathrm{ab} \\
21 \mathrm{a}\end{array}$ & $\begin{array}{l}37 b \\
44 b\end{array}$ \\
\hline & & & & & & \\
\hline & Sand & 1 & $80 \mathrm{a}$ & $128 \mathrm{~b}$ & $94 \mathrm{a}$ & $83 a$ \\
\hline & & 3 & $231 \mathrm{c}$ & $\begin{array}{l}123 a \\
219 b\end{array}$ & $\begin{array}{l}143 \mathrm{a} \\
197 \mathrm{ab}\end{array}$ & $\begin{array}{l}116 a \\
122 a\end{array}$ \\
\hline
\end{tabular}

$\mathrm{Cu}, \mu \mathrm{g} / \mathrm{g}$

Soil

$\begin{array}{rrrrr}1 & 6 a & 5 a & 4 a & 9 a \\ 2 & 5 a & 6 a & 5 a & 4 a \\ 3 & 7 a & 10 b & 9 b & 14 c\end{array}$

Values followed by the same letter in the same row do not differ significantly $(P<0.05)$. 
TABLE 4. Cationic Balance of Plants of Lactuca sativa L. at Different Stages of Growth in Sand (Mean values of three replicates in millequivalents).

\begin{tabular}{|c|c|c|c|c|c|c|c|c|c|c|}
\hline \multirow[b]{2}{*}{ Treat } & \multirow{2}{*}{$\begin{array}{l}\text { Stage of } \\
\text { Growth }\end{array}$} & \multicolumn{4}{|c|}{ Macronutrients $\times 10^{3}$} & \multicolumn{5}{|c|}{ Micronutrients x $10^{5}$} \\
\hline & & K Ca & $\mathrm{Mg}$ & $\mathrm{Na}$ & Total & $\mathrm{Cu}$ & Mn & & & Total \\
\hline bZnbFe & $\begin{array}{l}1 \\
2 \\
3\end{array}$ & $\begin{array}{rr}6.3 & 3.3 \\
14.1 & 7.2 \\
24.4 & 14.6\end{array}$ & $\begin{array}{l}1.2 \\
2.3 \\
4.2\end{array}$ & $\begin{array}{l}0.9 \\
1.5 \\
2.8\end{array}$ & $\begin{array}{l}11.7 \\
25.1 \\
45.9 \\
82.8\end{array}$ & $\begin{array}{l}0.4 \\
1.3 \\
2.3\end{array}$ & $\begin{array}{r}1.9 \\
7.3 \\
14.8\end{array}$ & $\begin{array}{r}3.5 \\
5.1 \\
11.1\end{array}$ & $\begin{array}{l}0.5 \\
1.4 \\
2.6\end{array}$ & $\begin{array}{r}6.2 \\
15.2 \\
30.8 \\
52.2\end{array}$ \\
\hline chZnchFe & $\begin{array}{l}1 \\
2 \\
3\end{array}$ & $\begin{array}{rr}5.3 & 3.0 \\
15.1 & 7.2 \\
16.7 & 12.4\end{array}$ & $\begin{array}{l}1.0 \\
2.7 \\
3.6\end{array}$ & $\begin{array}{l}0.6 \\
1.9 \\
2.1\end{array}$ & $\begin{array}{r}9.9 \\
26.8 \\
34.8 \\
71.5\end{array}$ & $\begin{array}{l}0.3 \\
2.3 \\
3.1\end{array}$ & $\begin{array}{r}2.0 \\
6.4 \\
10.9\end{array}$ & $\begin{array}{r}3.5 \\
8.9 \\
17.3\end{array}$ & $\begin{array}{l}0.7 \\
1.9 \\
3.5\end{array}$ & $\begin{array}{l}6.5 \\
19.5 \\
34.7 \\
60.7\end{array}$ \\
\hline
\end{tabular}

The total cationic content for both the macro- and micro-nutrients in the leaves of lettuce plants grown in sand and treated with chelates (chZnchFe treatment) or with basic salts (bZnbFe treatment) are given in Table 4. In this comparison, the possible influence of the soil or of either the chelates and basic salts (chZnbFe and bZnchFe treatments) are avoided. In Table 4, it can be seen that the accumulation is more regular through the different stages of growth and the final total content of the macronutrients was greater for the basic salts as compared to the chelates. Also it is evident that the lettuce plants were able to take up more micronutrients from the chelate form than that from the basic salts, expect for $\mathrm{Mn}$. It is possible that free chelating anions depress the availability of the macronutrients and $\mathrm{Mn}$ (Halvorson and Lindsay, 1977; Wallace and Wallace, 1983b).

The Fe/Mn ratio will increase if there is an interference between $\mathrm{Fe}$ and $\mathrm{Mn}$ (Knezek and Greinert, 1971). As is shown in Table 5, applying the chelates (chZnchFe treatment) to lettuce plants grown in soil, the $\mathrm{Fe} / \mathrm{Mn}$ ratios are higher than that for the basic salts (chZnbFe treatment), at least in the early stages of growth. For lettuce grown in sand, this effect does not appear.

Increasing the application rate of the $\mathrm{Fe}$ basic salt ( $\mathrm{bZn} 2 \mathrm{bFe}$ treatment), will increase the Fe/Mn ratio in lettuce leaves grown in sand as shown in Table 6. 
TABLE 5. Effect of the Chelates of Fe on the Fe/Mn Ratio of Plants of Lactuca sativa $\mathrm{L}$. at Different Stages of Growth (Mean values of three replicates).

\section{Ratio Fe/Mn}

\section{Stage of Growth}

Treatment

chZnbFe

chZnchFe

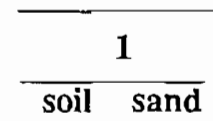

$3.52 \quad 1.60$

1.49

0.88

1.86

8.18

0.93

$\frac{2}{\text { soil } \quad \text { sand }}$

$6.17 \quad 1.32$

1.79

1.07

TABLE 6. The Fe/Mn Ratio of Plants of Lactuca sativa L. Given Increasing Quantities of the Basic Salt of Fe at Different Stages of Growth in Sand (Meanivalues of three replicates).

Ratio Fe/Mn

Stage of Growth

1

2

3

Treatment

$\mathrm{bZnl} / 2 \mathrm{bFe}$

0.83

0.96

$\mathrm{bZnbFe}$

$\mathrm{bZn} 2 \mathrm{bFe}$

These results seem to show that the presence of chelating anions is enhanced by the Fe-insolubilizing capacity of soils, which can induce a reduction of the $\mathrm{Mn}$ content in lettuce leaves, shown by the higher Fe/Mn ratios. The Fe-basic salt does not produce this effect when applied at the commercially recommended dose. Although no chlorotic symptoms were observed and there was no induction of nutrient imbalance, it is possible that there is increased competition for metabolic 
TABLE 7. Effect of the Chelates of $\mathrm{Zn}$ on the P Content of Plants of Lactuca sativa $\mathrm{L}$. at Different Stages of Growth (Mean values of three replicates).

\section{Ratio P/Zn}

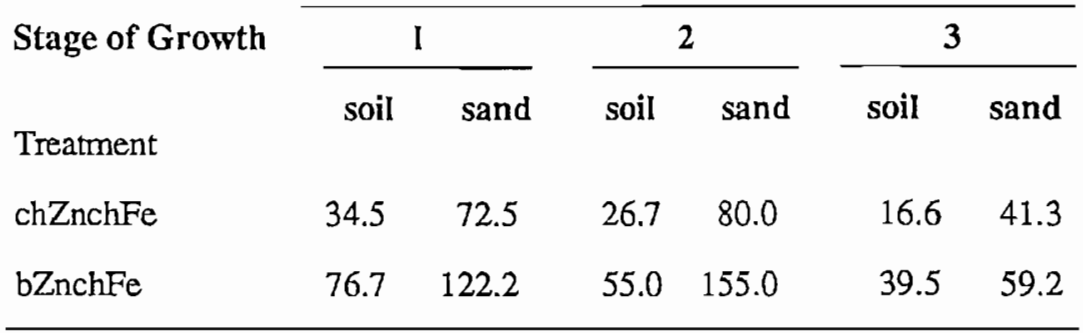

positions (Mengel and Kirkby, 1982; Olsen, 1972) with increased applications of the Fe-basic salt. This is in accord with the increasing values of the $\mathrm{Fe} / \mathrm{Mn}$ ratio during the later stages of growth (Table 6).

When a soil is well provided with $\mathrm{P}$, interferences in the transport of $\mathrm{Zn}$ into the plant can occur (Stukenholtz et al., 1966). The interference is shown through the appearance of high initial values for the $\mathrm{P} / \mathrm{Zn}$ ratio, which decreases to normal values in between $P / Z n=75$ and $P / Z n=300$ when larger doses of $\mathrm{Zn}$ are applied (Olsen, 1972). As shown in Table 7, when $\mathrm{Zn}$ chelate is added (chZnchFe treatment), the lettuce grown in sand and in soil show very low values for the $\mathrm{P} / \mathrm{Zn}$ ratio. This can be interpreted as the chelate giving excess $\mathrm{Zn}$ to the plant. The $\mathrm{P} / \mathrm{Zn}$ ratios given in Table 7 are near normal for lettuce grown in sand. When $\mathrm{Zn}$ is added as basic salt (bZnchFe treatment), the $\mathrm{P} / \mathrm{Zn}$ ratio is normal or near normal. This is especially so when lettuce is grown in sand, because the depressing effect of the presence of active calcium carbonate which affects the availability of $\mathrm{P}$ and $\mathrm{Zn}$ is absent (Udo et al., 1990). When the application rates are half or double than that commercially recommended are used as the basic salt $(1 / 2 \mathrm{bZnbFe}$ and $2 \mathrm{bZnbFe}$ treatment), the values of the $\mathrm{P} / \mathrm{Zn}$ ratio on lettuce grown on sand are normal and do not change, or change little, showing the ability of the basic salt to regulate the availability of the micronutrient (Table 8). The same can be deduced for the $\mathrm{Zn}-\mathrm{Fe}$ interaction. Rosell and Ulrich (1964) showed that plant leaves 
TABLE 8. The P/Zn Ratio of Plants of Lactuca sativa L. Given Increassing Quantities of the Basic Salt of $\mathrm{Zn}$ at Different Stages of Growth in Sand (Mean values of three replicates).

\begin{tabular}{lccc} 
& \multicolumn{3}{c}{ Ratio P/Zn } \\
\cline { 2 - 4 } $\begin{array}{l}\text { Stage of Growth } \\
\text { Treatment }\end{array}$ & 1 & 2 & 3 \\
$1 / 2 \mathrm{bZnbFe}$ & 113.8 & 114.8 & 209.9 \\
bZnbFe & 131.5 & 128.3 & 275.0 \\
$2 \mathrm{bZnbFe}$ & 144.4 & 127.5 & 248.8
\end{tabular}

TABLE 9. Effect of Increasing Quantities of the $\mathrm{Zn}$ Basic Salt on the Fe Content of Plants of Lactuca sativa L. Grown in Sand at Different Stages of Growth (Mean values of three replicates).

\begin{tabular}{lccc}
\hline & \multicolumn{3}{c}{ Fe, $\mu \mathrm{g} / \mathrm{g}$} \\
\cline { 2 - 4 } $\begin{array}{lcc}\text { Stage of Growth } \\
\text { Treatment }\end{array}$ & 1 & 2 & 3 \\
$1 / 2 \mathrm{bZnbFe}$ & 76.3 & 89.0 & 121.7 \\
$\mathrm{bZnbFe}$ & 78.3 & 99.0 & 135.5 \\
$2 \mathrm{bZnbFe}$ & 71.7 & 98.7 & 213.3 \\
$1 / 2 \mathrm{bZn} 1 / 2 \mathrm{bFe}$ & 73.0 & 94.7 & 113.3 \\
$1 / 2 \mathrm{bZn} 2 \mathrm{bFe}$ & 70.2 & 92.7 & 317.7 \\
\hline
\end{tabular}


compensate for $\mathrm{Zn}$ deficiency with $\mathrm{Fe}$ concentrations higher than normal. As shown in Table 9, lettuce grown in sand to which half or double the $\mathrm{Zn}$ commercial doses are added ( $1 / 2 \mathrm{bZnbFe}$ and $2 \mathrm{bZnbFe}$ treatments), have normal Fe values, below $350 \mathrm{ppm} \mathrm{Fe}$, and that the same happens when double doses of $\mathrm{Fe}$ are applied to lettuce which receive half doses of $\mathrm{Zn}(1 / 2 \mathrm{bZn} 2 \mathrm{Fe}$ treatment).

\section{CONCLUSION}

The basic salts of $\mathrm{Zn}$ or Fe can supply these elements to lettuce in a safe and convenient way. These basic salts do not interfere with the uptake of other elements, such as $\mathrm{P}$ or $\mathrm{Mn}$, and produce plants with adequate weight and correct nutritional status.

\section{ACKNOWLEDGEMENT}

The authors wish to acknowledge the statistical help in a part of the work to $\mathrm{Mr}$. L. N. Garcia, to Dr. C. Mazuelos for some of the analytical work and to Mr. M. Fernandez for greenhouse help and guidance. We thank Professor D. S. Jenkinson for his comments on the manuscript.

\section{REFERENCES:}

Galvez, M., Lopez-Delgado, A., Garcia, O., Cabrera, F., Osta, F., Fernandez, M., and Arambarri, P. 1987. La utilizacion de las sales basicas como aporte de micronutrientes. Proceedings 7th Congress NaI. Quimica (Sevilla) $1: 139-146$.

Geralson, C.M., Klacan, G.R., and Lorenz, O.A. 1973. Plant analysis as an aid in fertilizing vegetable crops, pp. 365-379. IN: L.M. Walsh and J.D. Beaton. Soil Testing and Plant Analysis. Soil Science Society of America, Inc., Madison, WI.

Halvorson, A.D. and Lindsay, W.L. 1977. The critical $\mathrm{Zn}^{2+}$ concentration for com and the non absorption of chelated $\mathrm{Zn}$. Soil Sci. Soc. Amer. J. 3: $531-534$.

Knezek, B.D. and Greinert, H. 1971. Influence of soil Fe and Mn EDTA interactions upon the Fe and Mn nutrition of bean plants. Agron. J. 63:617619. 
Lopez-Delgado, A., Garcia, O., and Galvez, M. 1988. Synthesis, characterization and thermal behaviour of $\mathrm{Fe} 4(\mathrm{OH})_{11} \mathrm{NO}_{3} \cdot 2 \mathrm{H}_{2} \mathrm{O}$. J. Therm. Anal. 34:843852.

Mattingly, G.E.G. 1965. The influence of intensity and capacity factors on the availability of soil phosphorus. Tech. Bull. Minst. Agric. Fish Food No. 13. H.M.S.O. London, England.

McGrath, S.P., Hirsch, P.R., and Giller, K.E. 1988. Effect of heavy metal contamination on the genetics of nitrogen-fixing population of Rhizobium leguminosarum nodulating white, pp. 164-166. IN: A.A. Orio (ed.) Environmental Contamination. CEP. Edinburgh, Scotland.

Mengel, K. and Kirkby, E.A. 1982. Principles of Plant Nutrition, pp. 617-619. International Potash Institute, Bern, Switzerland

Mortvedt, J.J. 1986. Iron sources and management practices for correcting iron chlorosis problems. J. Plant Nutr. 9:961-974.

Murphy, J. and Riley, J.P. 1962. A modified single solution method for the determination of phosphate in natural waters. Anal. Chem. Acta 27:31-36.

Olsen, S.R. 1972. Micronutrient interactions, pp. 243-264. IN: J.J. Mortvedt, P.M. Giordano, and W.L. Lindsay (eds.) Micronutrients in Agriculture. Soil Science Society of America, Madison, WI.

Parpian, P. and Anderson, W.B. 1988. Iron by product as influenced by selective dissolution techniques, acidification and soil reaction. J. Plant Nutr. 11: 1321-1331.

Pinta, M., 1973. Methodes de reference pour la determination des elements mineraux dans les vegetaux. Oleagineaux 28:87-92.

Pinta, M. and Laboratories Membres du Comite Inter-Institut d'etude des techniques analytiques du diagnostic foliare, 1973. Elements mineraux dans les vegetaux: $\mathrm{N}, \mathrm{P}, \mathrm{K}, \mathrm{Ca}$ et $\mathrm{Mg}$. Oleagineaux 24:497-504.

Rosell, R.A. and Ulrich, A. 1964. Critical zinc concentrations and leaf minerals of sugar beet plants. Soil Sci. 97:152-167

Stukenholtz, D.D., Olsen, R.J., Gogan, G., and Olson, R.A. 1966. On the mechanism of phosphorus-zinc interaction in corn nutrition. Proc. Soil Sci. Soc. Amer. 30:759-763.

Udo, E.J., Bohn, H.L., and Tucker, T.C. 1970. Zinc absorption by calcareous soils. Proc. Soil Sci. Soc. Amer. 34:405-407.

Wallace, A. 1983. A one-decade update on chelated metals for supplying micronutrients to crops. J. Plant Nutr. 6:428-438. 
Wallace, A. and Lunt, O.R. 1956. Reactions of some iron, zinc and manganese chelates in various soils. Soil Sci. Amer. Proc. 20:455-479.

Wallace, A. and Wallace, G.A. 1983a. DTPA as a source of $\mathrm{Zn}, \mathrm{Mn}, \mathrm{Cu}$ and $\mathrm{Fe}$ in calcareous soils. J. Plant Nutr. 6:451-455.

Wallace, A. and Wallace, G.A. 1983b. Zinc chelates inhibited uptake of copper and manganese or is it chelating agent inhibition? Differential zinc accumulation in primary leaves. J. Plant Nutr. 6:559-562.

Wempati, R.R. and Loeppert, R.H. 1986. Synthetic ferrhydrite as a potential iron amendment in calcareous soils. J. Plant Nutr. 9:1039-1052.

Wolnik, R.A., Fricke, F.L., Capar, S.G., Braude, G.L., Meyer, M.W., Satzger, R.D., and Kuennen, R.W. 1983. Elements in major raw agricultural crops in the United States. 2. Other elements in lettuce, peanuts, potatoes, soybeans, sweet com and wheat. J. Agric. Food Chem. 31:1244-1249. 